\title{
A Simple Method for the Quantitative Analysis of Tyrosol by HPLC in Liquid Czapek Cultures from Endophytic Fungi
}

\author{
Denise O. Guimarães, ${ }^{a}$ Keyller B. Borges, ${ }^{b}$ Pierina S. Bonato ${ }^{b}$ and Mônica T. Pupo ${ }^{*, a}$ \\ ${ }^{a}$ Departamento de Ciências Farmacêuticas and ${ }^{b}$ Departamento de Física e Química, Faculdade de Ciências \\ Farmacêuticas de Ribeirão Preto, Universidade de São Paulo, 14040-903 Ribeirão Preto-SP, Brazil
}

\begin{abstract}
O tirosol é provavelmente uma molécula sinalizadora em fungos endofíticos. A análise do tirosol em cultura líquida Czapek de fungo endofítico foi realizada através de cromatografia líquida de alta eficiência acoplada a detector por arranjo de diodos. As análises foram obtidas em sistema de fase móvel utilizando gradiente, modo linear, iniciando em acetonitrila/água $(1: 9 \mathrm{v} / \mathrm{v})$ e terminando em acetonitrila $100 \%$ em 30 minutos com vazão de $1 \mathrm{~mL} \mathrm{~min}^{-1}$. Coluna analítica ZORBAX ${ }^{\circledR}$ ODS $(250 \times 4,6 \mathrm{~mm}, 5 \mu \mathrm{m})$ à $25^{\circ} \mathrm{C}$ foi utilizada. Extração líquido-líquido de $0,5 \mathrm{~mL}$ do meio ( $\mathrm{pH} 7,0)$ com acetato de etila e injeção de $20 \mu \mathrm{L}$ após concentração do solvente sob ar comprimido originou bons resultados. Os parâmetros validados foram: linearidade 0,0125-5,0 $\mu \mathrm{g} \mathrm{mL}^{-1}(\mathrm{r}=0,9967)$, limite de quantificação $0,0125 \mu \mathrm{g} \mathrm{mL}^{-1}$ obtidos pela média das análises; \%CV (precisão) e \%E (exatidão) com valores abaixo de $15 \%$ e recuperação de cerca de $80 \%$. Além disso, o método desenvolvido apresentou valores de validação satisfatórios demonstrando eficiência na análise do tirosol em meio líquido Czapek.
\end{abstract}

Tyrosol is a possible quorum sensing molecule in endophytic fungi. High-performance liquid chromatography (HPLC) coupled with diode array detector (DAD) was used for the analysis of tyrosol in liquid Czapek fungal cultures. The optimized conditions were gradient mobile phase, in linear mode, consisting initially of acetonitrile/water $(1: 9 \mathrm{v} / \mathrm{v})$ and increasing up to acetonitrile $(100 \%)$ in 30 minutes at a flow rate of $1 \mathrm{~mL} \mathrm{~min}^{-1}$. The column used was a ZORBAX ${ }^{\circledR}$ ODS $(250 \times 4.6 \mathrm{~mm}, 5 \mu \mathrm{m})$ at $25{ }^{\circ} \mathrm{C}$. Liquid-liquid extraction of $0.5 \mathrm{~mL}$ medium $(\mathrm{pH} 7.0)$ with ethyl acetate and injection of $20 \mu \mathrm{L}$ after solvent evaporation under air flow gave good results. Some validation parameters obtained were: linearity $0.0125-5.0 \mu \mathrm{g} \mathrm{mL}^{-1}$ medium $(\mathrm{r}=0.9967)$,

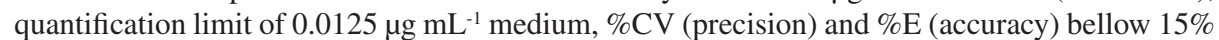
and recovery around $80 \%$. Therefore, the developed method presented satisfactory validation parameters and it was efficient for the analysis of tyrosol in Czapek medium.

Keywords: tyrosol, endophytic fungi, HPLC-DAD, validation method

\section{Introduction}

Tyrosol (2-(4-Hydroxyphenyl)ethanol) is a wellknown phenolic compound with antioxidant properties that is present in wine and olive oil, ${ }^{1}$ and it is reported to have scavenging effects on reactive oxygen and nitrogen species that are implicated in human pathologies such as cardiovascular and thrombotic diseases., ${ }^{2,3}$ Tyrosol is produced by terrestrial fungi and showed antifungal activity against Lagenidium callinectes ${ }^{4}$ and Gibberella pulicaris. ${ }^{5}$ Recently, tyrosol has been reported as a candidate to be used in stroke therapy due to its neuroprotective effect in rats. ${ }^{1}$ Moreover, tyrosol was identified as an autoregulatory

*e-mail: mtpupo@fcfrp.usp.br molecule with important implication on the dynamics of growth and morphogenesis in Candida albicans ${ }^{6}$ in a process known as quorum-sensing, which is characterized by a cellular density-dependent phenomenon. Quorumsensing effect is accomplished by the extracellular accumulation of small, self-generated chemical signaling molecules that induce bacterial population to produce the desired phenotypic effect. ${ }^{7}$ The first described quorumsensing system involved the bioluminescent marine bacterium Vibrio fischeri. ${ }^{8}$

Several chemical classes of microbial derived signaling molecules have been identified, and they might be classified in two main categories: $(i)$ amino acids and short peptides, commonly utilized by Gram-positive bacteria, ${ }^{9,10}$ and (ii) fatty acid derivatives, frequently utilized by Gram- 
negative bacteria. ${ }^{11,12}$ Particular emphasis has been placed on the wide range of quorum-sensing systems that employ $N$-acyl homoserine lactones (acyl HSLs) as the signaling molecules that control the expression of diverse physiological functions. ${ }^{12}$ Several examples of signaling molecules illustrate that quorum-sensing molecules have been used by microorganisms, especially bacteria, in order to control a great variety of functional systems. ${ }^{13}$ Studies of bacterial quorum-sensing phenomenon have shown information on how bacterial chemical communication works; how chemical information is integrated, processed and transduced to control gene expression; how intra- and inter species cell-cell communication is accomplished and the intriguing possibility of prokaryote-eukaryote crosscommunication. In fungi this phenomenon has been mostly studied in Candida albicans.

Due to its scavenging effects, tyrosol has been previously quantified in different matrices such as beverages ${ }^{14}$ and biological fluids (low-density-lipoprotein) ${ }^{15}$ using different analytical quantitative methods such as HPLC-DAD and HPLC-ESI-MS-MS.

In our prospection study of endophytic fungi from Asteraceae species we have isolated tyrosol from several bioactive endophytic cultures. So, we hypothesized it might have some quorum-sensing role in those microorganisms. In order to check this possibility, we initially set about developing a high-performance liquid chromatography (HPLC) coupled with diode array detector (DAD) method for the analysis of tyrosol in endophytic fungi cultures.

\section{Experimental}

\section{Standard solutions and chemicals}

Tyrosol utilized for the preparation of standard solutions was obtained from the cultivation of the endophytic fungus Glomerella cingulata (Stoneman) Spauld. \& H. Schrenk (code VA1) found in association with the host plant Viguiera arenaria (Asteraceae). The mycelium of G. cingulata grown on PDA (potato dextrose agar) Petri dishes was inoculated on 12 Erlenmeyer flasks containing $200 \mathrm{~mL}$ of pre-fermentative medium ${ }^{16}$ and incubated at $30^{\circ} \mathrm{C}$ with shaking $\left(120 \mathrm{rpm} \mathrm{min}^{-1}\right)$ for $24 \mathrm{~h}$. Afterward, the obtained mycelia were transferred to 12 Erlenmeyer flasks containing $400 \mathrm{~mL}$ of fermentative medium Czapek, ${ }^{17}$ and the fungus was allowed to grow at $30{ }^{\circ} \mathrm{C}$ and $120 \mathrm{rpm} \mathrm{min}^{-1}$ for an additional 144 hour period. The culture broth was separated from the mycelium through vacuum filtration $(400 \mathrm{~mL})$ and submitted to extraction with ethyl acetate (EtOAc) three consecutive times $(150 \mathrm{~mL}$ each). The EtOAc crude extract $(88.0 \mathrm{mg})$ was fractionated in a silica gel column $(0.063-0.200 \mathrm{~mm})$ with hexane/EtOAc (9:1 v/v); hexane/EtOAc (1:1 v/v); EtOAc and methanol. The sub fraction $25(6.4 \mathrm{mg})$, obtained with hexane/EtOAc $(1: 1 \mathrm{v} / \mathrm{v})$, was submitted to preparative thin layer chromatography in silica gel $\mathrm{PF}_{254}$ eluted with dichloromethane/methanol (9:1 v/v) yielding tyrosol (rf: 0.40, $5.0 \mathrm{mg}$ ). Tyrosol was extracted with acetone/methanol $(4: 1 \mathrm{v} / \mathrm{v}) .{ }^{18} \mathrm{NMR}$ spectra were acquired in Bruker spectrometers (DRX-400 and DRX500), working at 400 and $500 \mathrm{MHz}$ for ${ }^{1} \mathrm{H}$ and at 100 and $125 \mathrm{MHz}$ for ${ }^{13} \mathrm{C}$. The spectra were recorded in $\mathrm{CDCl}_{3}$, and the solvent signals at $\delta 7.26$ for proton, and $\delta 77.0$ for carbon, were used as reference. Mass spectra analysis was conducted in a mass spectrometer ESI-MS (Micromass Quattro LC-electrospray ionization). Chromatograms area analyses were compared in order to check the purity of isolated tyrosol and available commercial tyrosol $98 \%$ (Sigma-Aldrich Chemie, Steinheim, Germany). The purity index was $95.4 \%$ for isolated tyrosol used as standard for the quantitative validation procedures. Tyrosol stock standard solutions were prepared in methanol at concentrations of $0.250,0.500,1.0,5.0,20.0,60.0$ and $100.0 \mu \mathrm{g} \mathrm{mL}^{-1}$ (resulting in concentrations of 0.0125 , $0.0250,0.050,0.250,1.0,3.0$ and $5.0 \mu \mathrm{g} \mathrm{mL}^{-1}$ when $25 \mu \mathrm{L}$ is used to spike $0.5 \mathrm{~mL}$ culture medium). The solutions were stored at $-20^{\circ} \mathrm{C}$, in the absence of light.

HPLC-grade acetonitrile, methanol, ethyl acetate were purchased from Mallinckrodt Baker Inc. (Paris, USA) and ethyl acetate from Merck (Darmstadt, Germany). All other chemicals were of analytical-grade in the highest purity available. Water was distilled and purified using a Millipore Milli Q Plus system (Bedford, USA).

\section{Instrumentation and analytical conditions}

The analyses were carried out using a Shimadzu (Kyoto, Japan) HPLC system, consisting of a LC-6AD model solvent pump, system controller SCL 10A oven CTO-10AS ${ }_{\mathrm{VP}}$, a Rheodyne model 7725 injector with a $20 \mu \mathrm{L}$ loop, a SPD-M10A diode array detector operating at $225 \mathrm{~nm}$ and a software Class VP for data acquisition. The determination of tyrosol was performed on a ZORBAX ${ }^{\circledR}$ ODS column $(250 \times 4.6 \mathrm{~mm}$, I.D., $5 \mu \mathrm{m}$ particle size, Agilent Technologies, Exton, USA), protected with a 4.6 mm I.D. $\times 12.5 \mathrm{~mm} \times 4.6 \mathrm{~mm}, 4$-Pack endcapped guard column (Agilent Technologies), using a gradient mobile phase, in linear mode, consisting initially of acetonitrile/ water $(1: 9 \mathrm{v} / \mathrm{v})$ and increasing up to acetonitrile $(100 \%)$ in

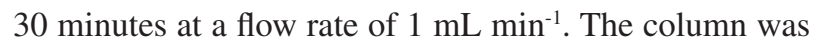
thermostated at $25^{\circ} \mathrm{C}$. 


\section{Extraction procedure}

Preliminary recovery studies were carried out in order to verify a satisfactory $\mathrm{pH}$ condition and solvent to be used in the liquid-liquid extraction procedure. Tyrosol standard solution was prepared at the concentration of $40.0 \mu \mathrm{g} \mathrm{mL}^{-1}$ (resulting in concentrations of 1.0 and $2.0 \mu \mathrm{g} \mathrm{mL}^{-1}$ when $25 \mu \mathrm{L}$ of this solution was used to spike 1 and $0.5 \mathrm{~mL}$ culture medium, respectively). Aliquots of $1 \mathrm{~mL}$ of Czapek medium at three different pHs: 5.0; 7.0 and 9.0 were spiked with $25 \mu \mathrm{L}$ of standard tyrosol solution at the concentration of $40.0 \mu \mathrm{g} \mathrm{mL}^{-1}$ and extracted with $3 \mathrm{~mL}$ ethyl acetate $(100 \%)$ or toluene/isopropanol (4:1 v/v). The tubes were capped and submitted to vortex mixing for $1 \mathrm{~min}$ and then centrifuged at $1800 \times \mathrm{g}$ for $4 \mathrm{~min}$. The upper organic phases $(2 \mathrm{~mL})$ were transferred to conical tubes and evaporated under compressed air. The dried residues were dissolved in $50 \mu \mathrm{L}$ of the mobile phase ( $10 \%$ acetonitrile aqueous solution) and $20 \mu \mathrm{L}$ were chromatographed under the previously described conditions.

In order to verify whether the phosphate buffer $1 \mathrm{~mol} \mathrm{~L}^{-1}$, $\mathrm{pH} 7.0$ solution was satisfactory to maintain a neutral $\mathrm{pH}$ at 7.0 for liquid-liquid extraction another procedure was tested: aliquots of $0.5 \mathrm{~mL}$ of the Czapek matrix spiked with $25 \mu \mathrm{L}$ of the standard tyrosol solution $\left(40.0 \mu \mathrm{g} \mathrm{mL}^{-1}\right)$ were neutralized with $1 \mathrm{~mL} 1 \mathrm{~mol} \mathrm{~L}^{-1}$ phosphate buffer solution $\mathrm{pH} 7.0$ and extracted with $4 \mathrm{~mL}$ ethyl acetate. The upper organic phases $(3 \mathrm{~mL})$ were transferred to conical tubes and evaporated under compressed air. The dried residues were dissolved in $100 \mu \mathrm{L}$ of the mobile phase (10\% acetonitrile aqueous solution) and $20 \mu \mathrm{L}$ were chromatographed under the previously described conditions.

Good results were obtained with this last described extraction procedure, which was used for the method validation and method application by samples analyses. In addition, the room temperature was set at $22 \pm 2{ }^{\circ} \mathrm{C}$ in order to prevent solvent evaporation during sample preparation.

\section{Method validation}

Calibrations curves were obtained by spiking aliquots of $0.5 \mathrm{~mL}$ medium with standard solutions of tyrosol, prepared in methanol, in the range of $0.250-100.0 \mu \mathrm{g}$ $\mathrm{mL}^{-1}$, resulting in concentrations of $0.0125-5.0 \mu \mathrm{g} \mathrm{mL}^{-1}$ in the culture medium. No internal standard was used in this method.

To determine the extraction recovery, medium samples $(0.5 \mathrm{~mL})$ were spiked with tyrosol in the concentrations of $0.05,1.0$ and $5.0 \mu \mathrm{g} \mathrm{mL} \mathrm{m}^{-1}(\mathrm{n}=3)$ and submitted to the extraction procedure. Another set of samples were prepared extracting $0.5 \mathrm{~mL}$ aliquots of medium and then spiking the extract with the same amount of tyrosol. The recovery was determined by comparing the areas obtained before and after extraction and was expressed as percentage of the amount extracted.

The detectability of the method was evaluated by determining the quantification limit (LOQ). The LOQ was defined as the lowest concentration that could be determined with accuracy and precision below $20 \%{ }^{19}$ over five analytical run and it was obtained using medium samples $(0.5 \mathrm{~mL}, \mathrm{n}=5)$ spiked with concentrations of $0.0125 \mu \mathrm{g} \mathrm{mL}-1$ of tyrosol.

The precision and accuracy of the method were evaluated by analyzing spiked matrix with known standard tyrosol solution. The experiments were carried out by intra-day $(\mathrm{n}=5)$ and inter-day $(\mathrm{n}=3)$ assays using medium samples spiked with tyrosol at the concentrations of $0.0250,0.250$ and $3.0 \mu \mathrm{g} \mathrm{mL} \mathrm{m}^{-1}$. The results obtained were expressed as coefficient of variation $(\mathrm{CV}, \%)$ and relative error $(\mathrm{E}, \%)$.

The selectivity of the method was evaluated by analyzing sterile medium (blank) and endophytic fungal culture broth under the conditions previously established.

The stability of tyrosol was evaluated by testing the influence of freeze $\left(-20^{\circ} \mathrm{C}\right)$ and thaw $\left(22 \pm 2^{\circ} \mathrm{C}\right)$ cycles, short-term room temperature and 48 - $\mathrm{h}$ freeze temperature. Spiked Czapek media were prepared in sextuplicate $(n=6)$ at the low $\left(0.05 \mu \mathrm{g} \mathrm{mL}^{-1}\right)$ and high concentration $(3 \mu \mathrm{g} \mathrm{mL}$ $\left.{ }^{1}\right)$. To perform the freeze-thaw cycle stability test, these samples were stored at $-20{ }^{\circ} \mathrm{C}$ for $24 \mathrm{~h}$ and thawed at room temperature. When completely thawed, the samples were refrozen for $12 \mathrm{~h}$ under the same conditions. The freeze-thaw cycle was repeated once more, and then the samples were analyzed on the second cycle. The $48 \mathrm{~h}$ freeze temperature stability test was performed analyzing frozen $\left(-20^{\circ} \mathrm{C}\right)$ Czapek medium samples over $48 \mathrm{~h}$. This period corresponds to the maximum time the samples were kept frozen. The short-term room temperature stability test was assessed analyzing samples that were kept on the bench-top for $4 \mathrm{~h}$ at room temperature $\left(22 \pm 2{ }^{\circ} \mathrm{C}\right)$. After this period, the samples were analyzed. The peak area obtained from the stability tests was compared to the peak area obtained with freshly prepared samples. Student's t test was applied, with the level of significance set at $\mathrm{p} \leq 0.05$.

\section{Endophytic fungus isolation and tyrosol formation}

The fungus $G$. cingulata used in these experiments was previously isolated as endophyte from $V$. arenaria (Asteraceae) and identified by its rDNA sequence. ${ }^{18}$ The strain has been maintained on potato dextrose agar slants and silica-gel (1-4 mm Synth, Brazil) and stored at $4{ }^{\circ} \mathrm{C}$. The 
Table 1. Tyrosol optimization of extraction procedure

\begin{tabular}{|c|c|c|c|c|c|c|c|c|c|c|c|c|c|c|c|c|c|c|}
\hline \multirow[b]{3}{*}{$\begin{array}{r}\text { Concentration / } \\
\left(\mu \mathrm{g} \mathrm{mL} L^{-1} ; \mathrm{n}^{\mathrm{a}}=4\right)\end{array}$} & \multicolumn{6}{|c|}{$\begin{array}{l}\text { Tyrosol extracted with toluene/ } \\
\text { isopropanol (4:1) }\end{array}$} & \multicolumn{6}{|c|}{ Tyrosol extracted with EtOAc $100 \%$} & \multicolumn{6}{|c|}{$\begin{array}{l}\text { Tyrosol extracted with EtOAc } 100 \% \text { after } \\
\text { addition of phosphate buffer } \mathrm{pH} 7.0^{*}\end{array}$} \\
\hline & \multicolumn{2}{|c|}{$\mathrm{pH} 5.0$} & \multicolumn{2}{|c|}{$\mathrm{pH} 7.0$} & \multicolumn{2}{|c|}{ pH 9.0} & \multicolumn{2}{|c|}{ pH 5.0} & \multicolumn{2}{|c|}{$\mathrm{pH} 7.0$} & \multicolumn{2}{|c|}{$\mathrm{pH} 9.0$} & \multicolumn{2}{|c|}{$\mathrm{pH} 5.0$} & \multicolumn{2}{|c|}{$\mathrm{pH} 7.0$} & \multicolumn{2}{|c|}{$\mathrm{pH} 9.0$} \\
\hline & $\begin{array}{c}\text { Recovery/ } \\
(\%)^{\mathrm{b}}\end{array}$ & $\begin{array}{l}\mathrm{CV} / \\
(\%)^{\mathrm{c}}\end{array}$ & $\begin{array}{c}\text { Recovery/ } \\
(\%)^{\mathrm{b}}\end{array}$ & $\begin{array}{l}\mathrm{CV} / \\
(\%)^{\mathrm{c}}\end{array}$ & $\begin{array}{c}\text { Recovery/ } \\
(\%)^{\mathrm{b}}\end{array}$ & $\begin{array}{l}\mathrm{CV} / \\
(\%)^{\mathrm{c}}\end{array}$ & $\begin{array}{c}\text { Recovery/ } \\
(\%)^{\mathrm{b}}\end{array}$ & $\begin{array}{l}\mathrm{CV} / \\
(\%)^{\mathrm{c}}\end{array}$ & $\begin{array}{c}\text { Recovery/ } \\
(\%)^{\mathrm{b}}\end{array}$ & $\begin{array}{l}\mathrm{CV} / \\
(\%)^{\mathrm{c}}\end{array}$ & $\begin{array}{c}\text { Recovery/ } \\
(\%)^{\mathrm{b}}\end{array}$ & $\begin{array}{l}\mathrm{CV} / \\
(\%)^{\mathrm{c}}\end{array}$ & $\begin{array}{c}\text { Recovery/ } \\
(\%)^{\mathrm{b}}\end{array}$ & $\begin{array}{l}\mathrm{CV} / \\
(\%)^{\mathrm{c}}\end{array}$ & $\begin{array}{c}\text { Recovery/ } \\
(\%)^{\mathrm{b}}\end{array}$ & $\begin{array}{l}\mathrm{CV} / \\
(\%)^{\mathrm{c}}\end{array}$ & $\begin{array}{c}\text { Recovery/ } \\
(\%)^{\mathrm{b}}\end{array}$ & $\begin{array}{l}\mathrm{CV} / \\
(\%)^{\mathrm{c}}\end{array}$ \\
\hline 1.0 & 31.6 & 0.4 & 33.7 & 6.2 & 27.6 & 8.6 & 66.8 & 11.3 & 74.8 & 3.6 & 49.6 & 9.6 & 90.7 & 8.6 & 92.6 & 13.4 & 92.7 & 12.8 \\
\hline
\end{tabular}

${ }^{\mathrm{a}}$ Number of determinations; ${ }^{\mathrm{b}}$ mean recovery; ${ }^{\mathrm{C}} \mathrm{CV}$, coefficient of variation. ${ }^{*}$ Concentration used: $2.0 \mu \mathrm{g} \mathrm{mL}{ }^{-1}$.

strain was deposited in the "Laboratório de Enzimologia Industrial-FCFRP/USP".

G. cingulata was cultured using a two-step fermentative process. First, suspension of the mycelium was aseptically inoculated into $1000 \mathrm{~mL}$ Erlenmeyer flasks containing $200 \mathrm{~mL}$ of seed medium. ${ }^{16}$ The flasks were incubated for $48 \mathrm{~h}$ at $30{ }^{\circ} \mathrm{C}$ on a rotary shaker (New Brunswick Scientific Co., Inc., model INNOVA TM 4300, New Jersey, USA) operating at $120 \mathrm{rpm}$. The resulting mycelia obtained after seed medium filtration were transferred into $2000 \mathrm{~mL}$ Erlenmeyer flasks containing $400 \mathrm{~mL}$ of Czapek medium. ${ }^{17}$ Three different $\mathrm{pHs}$ were adopted for the cultivation on Czapek medium: $\mathrm{pH}$ 5.0, 7.0 and 9.0. Experiments were carried out at $30^{\circ} \mathrm{C}$, with shaking at $120 \mathrm{rpm}$ for additional 20 days. Aliquots of the Czapek filtrates $(0.5 \mathrm{~mL})$ after mycelium inoculation were submitted to the previously described extraction procedure and analyzed by HPLC.

\section{Results and Discussion}

\section{Method development and liquid-liquid extraction}

Analyses were carried out using a ZORBAX-ODS column $(250 \mathrm{~mm} \times 4.6 \mathrm{~mm}$ I.D. $)$ and a linear gradient elution consisting initially of acetonitrile/water $(1: 9 \mathrm{v} / \mathrm{v})$ and increasing up to acetonitrile $(100 \%)$ in 30 minutes. Analyses of the blank of the Czapek medium (Figure 1A) showed no interference at the retention time for tyrosol $\left(\mathrm{t}_{\mathrm{R}}=10.05 \mathrm{~min}\right)$ (Figure 1B). In addition, the UV profile of tyrosol is represented at Figure 1C.

The utilization of the gradient linear mode and the absence of an internal standard were related to the complexity of the endophytic fungi extracts that might be obtained from Czapek culture medium. In this case, an internal standard might interfere in the extracts' analyses. In addition, the gradient mode contributes for a better separation of the compounds in a complex extract.

Preliminary recovery studies (Table 1) show that ethyl acetate at $\mathrm{pH} 7.0$ was the best condition for liquid-liquid extraction of tyrosol. In order to establish the $\mathrm{pH}$ of the culture broth after fungal cultivation, we performed the addition of the phosphate buffer $1 \mathrm{~mol} \mathrm{~L}^{-1}, \mathrm{pH} 7.0$ to the Czapek medium ( $\mathrm{pH}$ 5.0, 7.0 and 9.0) before the extraction with ethyl acetate. Recovery values for extraction of tyrosol after addition of the phosphate buffer using three different pHs were similar (Table 1) illustrating that addition of this buffer solution was efficient to maintain the $\mathrm{pH}$ of the medium at 7.0 in order to guarantee a satisfactory $\mathrm{pH}$ for the tyrosol extraction.

\section{Method validation}

The calibration curves were linear over the concentration range of $0.0125-5.0 \mu \mathrm{g} \mathrm{mL} \mathrm{m}^{-1}$ for tyrosol with linear equation: $\mathrm{y}=122534 \mathrm{x}+3240.4$; correlation coefficient (r) of 0.9967 and coefficient of variation of $13.9 \%$. The lowest concentration quantified by the validated method was $0.0125 \mu \mathrm{g} \mathrm{mL} \mathrm{m}^{-1}$ with coefficient of variation of $13.7 \%$ and error $13.9 \%$. Recoveries were around $80 \%$ for tyrosol with coefficients of variation lower than $15 \%$ (Table 2). Intra-day $(\mathrm{n}=5)$ and inter-day $(\mathrm{n}=3)$ precision and accuracy presented coefficients of variation and relative errors lower than 15\% (Table 3). In spite of not using an internal standard, the precision results were acceptable.

Stability of tyrosol in Czapek medium was evaluated by Student's $t$ test with the level of significance set at $\mathrm{p} \leq 0.05$. The p-values obtained were above 0.05 illustrating the stability of tyrosol. Coefficients of variation obtained for low and high concentration used in stability test were lower than $15 \%$ (Table 4).

Table 2. Recovery of tyrosol

\begin{tabular}{lcc}
\hline $\begin{array}{l}\text { Concentration / } \\
\left(\mu \mathrm{g} \mathrm{mL}{ }^{-1} ; \mathrm{n}^{\mathrm{a}}=3\right)\end{array}$ & Recovery / $(\%)$ & $\mathrm{CV}^{\mathrm{b}} /(\%)$ \\
\hline 0.05 & 73.5 & 11.0 \\
1.0 & 89.6 & 2.6 \\
5.0 & 79.0 & 3.1 \\
Mean & 80.7 & 11.8 \\
\hline
\end{tabular}

${ }^{\mathrm{a}}$ number of determinations; ${ }^{\mathrm{b}} \mathrm{CV}$, coefficient of variation. 

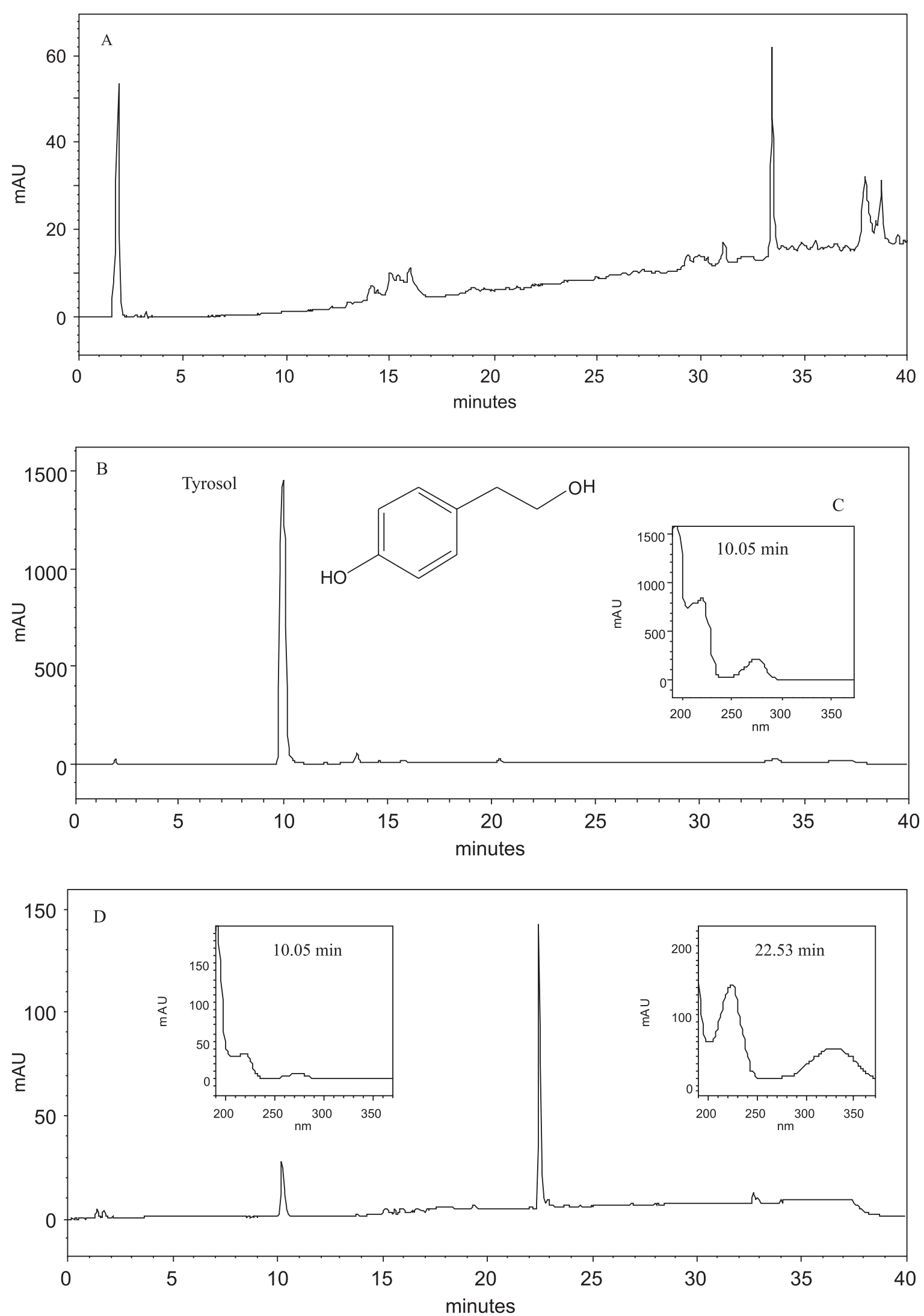

Figure 1. (A) Chromatogram referring to the analysis of medium culture blank. (B) Chromatogram referring to the analysis of tyrosol $t_{\mathrm{R}}=10.05$ min; purity: 0.99990 at $1 \mathrm{mg} \mathrm{mL}^{-1}$. (C) UV-Profile of standard solution of tyrosol in 190-370 nm. (D) Chromatogram referring to the analysis of Glomerella cingulata culture media after $144 \mathrm{~h}$ of incubation. 
Table 3. Precision and accuracy of the method for analysis of tyrosol in Czapek medium

\begin{tabular}{lccccccc}
\hline & \multicolumn{3}{c}{ Intra-day $\left(\mathrm{n}^{\mathrm{a}}=5\right)$} & & \multicolumn{3}{c}{ Inter-day $\left(\mathrm{n}^{\mathrm{a}}=3\right)$} \\
\cline { 2 - 4 } \cline { 5 - 7 } Nominal concentration / $\left(\mu \mathrm{g} \mathrm{mL}^{-1}\right)$ & 0.0250 & 0.250 & 3.00 & & 0.0250 & 0.250 & 3.00 \\
Analyzed concentration / $\left(\mu \mathrm{g} \mathrm{mL}^{-1}\right)$ & 0.0256 & 0.250 & 2.85 & & 0.0250 & 0.231 & 2.66 \\
Precision / $(\mathrm{CV}, \%)^{\mathrm{b}}$ & 9.8 & 8.5 & 5.9 & & 14.5 & 11.3 & 8.9 \\
Accuracy / $(\mathrm{E}, \%)^{\mathrm{c}}$ & 2.3 & 0.1 & -4.8 & & -0.0 & -7.6 & -11.2 \\
\hline
\end{tabular}

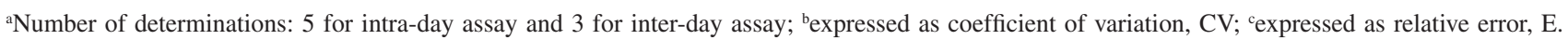

Table 4. Stability test of tyrosol

\begin{tabular}{|c|c|c|c|c|}
\hline \multirow{2}{*}{$\begin{array}{l}\text { Nominal concentration / } \\
\left(\mu \mathrm{g} \mathrm{mL} L^{-1}, \mathrm{n}^{\mathrm{a}}=6\right)\end{array}$} & \multicolumn{4}{|c|}{ tyrosol } \\
\hline & Tyrosol concentration $($ mean $) /\left(\mu \mathrm{g} \mathrm{mL}^{-1}\right)$ & $\mathrm{CV}^{\mathrm{b}} /(\%)$ & $\mathrm{E}^{\mathrm{c}} /(\%)$ & $p$-value \\
\hline \multicolumn{5}{|l|}{ Fresh } \\
\hline 0.05 & 0.0509 & 2.78 & 1.92 & - \\
\hline 3.00 & 3.1454 & 7.88 & 4.84 & - \\
\hline \multicolumn{5}{|l|}{ Freeze-thaw cycles } \\
\hline 0.05 & 0.0497 & 1.64 & -0.46 & 0.10 \\
\hline 3.00 & 2.9625 & 1.71 & 1.25 & 0.11 \\
\hline \multicolumn{5}{|l|}{$48 \mathrm{~h}$ freeze } \\
\hline 0.05 & 0.0497 & 1.80 & -0.48 & 0.11 \\
\hline 3.00 & 3.0004 & 10.46 & 0.01 & 0.39 \\
\hline \multicolumn{5}{|c|}{ Short-term room temperature } \\
\hline 0.05 & 0.0504 & 0.74 & 0.86 & 0.39 \\
\hline 3.00 & 2.9253 & 0.80 & 2.49 & 0.06 \\
\hline
\end{tabular}

${ }^{\mathrm{a}}$ number of determinations; ${ }^{\mathrm{b}} \mathrm{CV}$, coefficient of variation. ${ }^{\mathrm{c}}$ Expressed as relative error, E.

\section{Method application}

The developed method showed to be efficient for the quantitative analyses of tyrosol in Czapek fermentative medium. The method was applied for a Czapek sample derived from the cultivation of the endophytic fungus Glomerella cingulata and no interference for tyrosol peak was observed, since the peak purity indexes were above 0.99000 for all analyses. These analyses were carried out after inoculation of the mycelia obtained from seed medium into Czapek medium at three different $\mathrm{pHs}$ (5.0, 7.0 and 9.0) without leaving any additional time of incubation (incubation time $=0 \mathrm{~h}$ ) and with $144 \mathrm{~h}$ of incubation (chromatogram of $144 \mathrm{~h}$ of incubation time is shown in Figure 1D). Concentration of tyrosol at $0 \mathrm{~h}$ of incubation was 0.04 (CV 9.9\%); 0.03 (CV 7.4\%) and $0.04(\mathrm{CV} 11.1 \%) \mu \mathrm{g} \mathrm{mL} \mathrm{m}^{-1}$ for cultures at $\mathrm{pHs}$ at 5.0, 7.0 and 9.0, respectively. For the $144 \mathrm{~h}$ incubation time the concentration of tyrosol found was 2.27 (CV 4.1\%); 1.18 (CV 3.4\%) and $1.12(\mathrm{CV} 7.3 \%) \mu \mathrm{g} \mathrm{mL}^{-1}$ for cultures at $\mathrm{pH}$ at 5.0, 7.0 and 9.0, respectively. The presence of tyrosol at similar concentrations for the three different culturing conditions at 0 hour of incubation means that tyrosol production probably starts during the seed medium culture. The chromatogram in Figure 1D refers to the analysis of tyrosol at $144 \mathrm{~h}$ of incubation of Glomerella cingulata in Czapek medium. Analysis of the peak purity index (1.00000) by DAD at $t_{R}=10.05$ min shows that no influence of other secondary metabolites were observed. Moreover, the presence of the peak at $t_{R}=22.53$ min illustrates that the validated method can be used to verify the correlation between tyrosol and other secondary metabolites produced by fungi in Czapek medium. Is is noteworthy that as the production of tyrosol increases in the culture medium, the production of compound at $t_{R}=22.53$ min also increases, as illustrated by the chromatogram in Figure 1D. It suggests that tyrosol might be acting as a signaling compound for the production of this additional metabolite.

Tyrosol and other antioxidant compounds that are believed to play a vital role in the prevention of coronary disease and atherosclerosis have received special attention in the development of quantitative methods. Different 
matrices such as human plasma, human low density lipoproteins ${ }^{15}$ and ciders ${ }^{14}$ using basically HPLC or HPLCESI-MS-MS as main techniques have been employed for the quantification of these antioxidant compounds. Both isocratic and gradient linear methods can be found for quantitative analyses of tyrosol and the time of analysis varies from a shor $\mathrm{t}^{20}$ through long periods ${ }^{14}$ depending on the main objective of the study. To our concern there are no published data for the analysis of tyrosol in Czapek medium.

\section{Conclusions}

A suitable high-performance liquid chromatography method was developed and validated for the determination of tyrosol in fermentative Czapek medium. This method was successfully used to quantify the formation of tyrosol by the endophytic fungus $G$. cingulata cultured at different pHs. Therefore, this analytical quantitative method might be used for the detection and quantification of tyrosol in Czapek medium of endophytic fungi under different culturing conditions. In addition, the development of sample preparation and appropriate concentration procedure might extend the applicability of this method to other matrices. Finally, this method will allow further studies in order to verify the role of tyrosol as a quorum-sensing signaling molecule for the secondary metabolites production by endophytic fungi from Asteraceae species.

\section{Acknowledgments}

The authors are grateful to Fundação de Amparo à Pesquisa do Estado de São Paulo (FAPESP), sub-program BIOTA/FAPESP (Rede BIOprospecTA), Conselho Nacional de Desenvolvimento Científico e Tecnológico (CNPq) and to Coordenação de Aperfeiçoamento de Pessoal de Nível Superior (CAPES) for financial support and for granting research fellowships (FAPESP grants 03/07535-5, 04/07935-6, 05/03791-2).

\section{References}

1. Bu, Y.; Rho, S.; Kim, J.; Kim, M. K.; Lee, D. H.; Kim, S. Y.; Choi, H.; Kim, H.; Neurosci. Lett. 2007, 414, 218.
2. de la Puerta, R.; Martinez Domínguez, M. E.; Ruiz-Gutierrez, V.; Flavill, J. A.; Hoult, J. R.; Life Sci. 2001, 69, 1213.

3. Bertelli, A. A.; Migliori, M.; Panichi, V.; Longoni, B.; Origlia, N.; Ferretti, A.; Cuttano, M. G.; Giovannini, L.; Ann. N. Y. Acad. Sci. 2002, 957, 295.

4. Sofia, M.; Turnes, G.; Fenical, W.; Biol. Bull. 1992, 182, 105.

5. Slininger, P. J.; Burkhead, K. D.; Schisler, D. A.; J. Ind. Microbiol. Biotechnol. 2004, 31, 517.

6. Chen, H.; Fujita, M.; Feng, Q.; Clardy, J.; Fink, G. R.; Proc. Natl. Acad. Sci. U. S. A. 2004, 101, 5048.

7. De Kievit, T. R.; Iglweski, B. H.; Infect. Immun. 2000, 68, 4839.

8. Nealson, K. H.; Hastings, J. W.; Microbiol. Rev. 1979, 43, 496.

9. Lazazzera, B. A.; Grossman, A. D.; Trends Microbiol. 1998, 6, 288.

10. Shapiro, J. A.; Annu. Rev. Microbiol. 1998, 52, 81.

11. Dunny, G. M.; Winans, S. C.; Cell-cell Signaling in Bacteria; ASM Press: Washington, D. C., 1999.

12. Whitehead, N. A.; Barnard, M. L.; Slater, H.; Simpson, N. J. L.; Salmond, G. P. C.; FEMS Microbiol. Rev. 2001, 25, 365.

13. Gera, C.; Srisvastava, S.; Current Sci. 2006, 90, 666.

14. Suaréz, B.; Palacios, N.; Fraga, N.; Rodríguez, R.; J. Chromatogr. A 2005, 1066, 105.

15. de la Torre-Carbot, K.; Jauregui, O.; Castellote, A. I.; LamuelaRaventós, R. M.; Covas, M. -I.; Casals, I.; Lópes-Sabater, M. C.; J. Chromatogr. A 2006, 1116, 69.

16. Jackson, M.; Karwoswski, J. P.; Humphrey, P. E.; Kohl, W. L.; Barlow, G. J.; Tanaka, S. K.; J. Antibiot. 1993, 46, 34.

17. Alviano, C. S.; Farbiarz, S. R.; Travassos, L. R.; Angluster, J.; Souza, W.; Mycopathologia 1992, 119, 17.

18. Guimarães, D. O.; Borges, W. S.; Kawano, C. Y.; Ribeiro, P. H.; Goldman, G. H.; Nomizo, A.; Thiemann, O. H.; Oliva, G.; Lopes, N. P.; Pupo, M. T.; FEMS Immunol. Med. Microbiol. 2008, 52, 134.

19. http://www.fda.gov/cder/guidance/4252fnl.pdf, accessed in May 2008.

20. Grizis, C.; Atta-Politou, J.; Koupparis, M. A.; J. Liq. Chromatogr. Relat. Technol. 2003, 26, 599.

Received: May 12, 2008

Web Release Date: November 18, 2008

FAPESP helped in meeting the publication costs of this article. 